https://ejournal.uniska-kediri.ac.id/index.php/Diversi

P-ISSN: 2503 - 4804, E-ISSN: 2614 - 5936, DOI : 10.32503

\title{
ANAK HASIL PERKA WINAN SIRI SEBAGAI AHLI WARIS DITINJAU DARI HUKUM PERDATA DAN HUKUM ISLAM
}

\author{
Ury Ayu Masitoh \\ Fakultas Hukum Universitas Islam Kadiri \\ Jl. Sersan Suharmaji Nomor. 38, Manisrenggo, Kota Kediri, Kediri, \\ Jawa Timur 64128, Indonesia \\ urrymachittoh@gmail.com
}

\begin{abstract}
Development of a modern period and globalization have increased various social interaction. Such interaction may vary from free sex to unregistered marriage to cover disgrace. The status of children resulted in unregistered marriage is not clear in society whether they are legitimate or not, especially in terms of inheritance. There are three laws of inheritance prevailing in Indonesia, each has advantages and disadvantages, as well as different purpose. This research proposes to reveal the status of children resulted from unregistered marriage in accordance with the Indonesia positive laws, and that according to Islamic Law. This research is a legal research. The approach used is the statutory approach by reviewing the laws related to the inheritance of unregistered marriage, and comparative approach by comparing two existing inheritance laws in Indonesia, that is civil law and Islamic law. Children from unregistered marriage Have the same position as legitimate children in Indonesian law Nevertheless, there are two things that make difference, that is in term of identity and in inheritance, children from unregistered marriage Have the same position and part of inheritance as legitimate children, provided that the children have been authorized. While in Islamic law, children from the unregistered marriage and legitimate marriage have the same position although they have not been authorized. In both perspectives, marriage should be registered and get a certificate, otherwise, the children are categorized as those of outside marriage. So that, without recording a child's identity, that children considered outsider child.
\end{abstract}

Keywords : Children, Inheritance, Unregistered marriage. ${ }^{1}$

\begin{abstract}
ABSTRAK
Perkembangan era modern dan globalisasi menimbulkan interaksi sosial yang beraneka ragam. Interaksi tersebut bisa menimbulkan free sex hingga pelaku memilih melakukan perkawinan siri untuk menutup aib. Kedudukan anak hasil siri dalam hukum pun tidaklah jelas bagi masyarakat apakah anak tersebut sah atau tidak, terutama dalam hal kewarisan. Terdapat tiga hukum kewarisan yang berlaku di indonesia dimana tiap hukum waris memiliki kelebihan dan kekurangan masing-masing dimana hukum tersebut sangat memiliki perbedaan. Rumusan masalah dalam penelitian ini adalah bagaimana kedudukan anak hasil perkawinan siri menurut hukum yang berlaku di Indonesia serta bagaimana kedudukan anak
\end{abstract}

${ }^{1}$ Submission : 08 -11-2018 I Review - 1: 10 - 11 - 2018 I Review - 2: 30 - 11 - 2018 I Production : $28-2-2019$ 
luar kawin hasil perkawinan siri sebagai ahli waris menurut hukum perdata dan hukum Islam. Penelitian ini merupakan penelitian hukum yuridis normatif. Pendekatan masalah yang digunakan adalah pendekatan Undang-Undang (statue approach) yaitu dengan mengkaji ulang Undang-Undang terkait pewarisan anak hasil perkawinan siri dan pendekatan komparatif (comparative approach) dengan membandingkan dua hukum kewarisan yang ada di Indonesia, yaitu hukum perdata dan Islam. Anak hasil perkawinan siri memiliki kedudukan yang sama dengan anak sah di mata hukum Indonesia. Meskipun demikian tetap ada dua hal yang dibedakan, yakni dalam soal identitas dan pewarisan. Dalam pandangan hukum perdata, anak hasil perkawinan siri memiliki kedudukan dan bagian waris yang sama dengan anak sah asalkan anak tersebut telah disahkan. Sedangkan dalam hukum Islam anak hasil perkawinan siri dan anak sah memiliki kedudukan yang sama meskipun tidak disahkan. Dalam kedua pandangan hukum, suatu perkawinan yang ada haruslah mendapat akta nikah dari pegawai pencatatan.sehingga tanpa adanya pencatatan dalam identitas anak, anak tersebut dianggap anak luar kawin.

Kata Kunci : Anak, Perkawinan siri, waris 


\section{Pendahuluan}

Pada masa sekarang, di tengah perkembangan zaman yang semakin pesat tentunya melahirkan dampak interaksi sosial yang semakin berkembang pula. Salah satu dampak buruknya adalah munculnya pergaulan bebas yang ditandai dengan adanya perilaku menyimpang dari norma, seperti pesta miras, pesta narkoba ataupun Free sex yang kebanyakan dilakukan oleh remaja maupun masyarakat yang sudah dewasa khususnya para pekerja seks.

Lebih jauh, sebagai dampak buruk dari adanya Free sex tersebut, maka melahirkan berbagai permasalahan sosial baru, seperti munculnya penyakit kelamin atau adanya kehamilan sebelum terjadi pernikahan yang melahirkan anak luar kawin. Buruknya, bagi seorang pelaku free sex yang tidak mau memiliki anak luar kawin, akan berusaha melakukan aborsi ketika anak tersebut didalam kandungan atau membuangnya ketika telah lahir. Padahal anak merupakan anugrah sekaligus penerus generasi suatu keluarga yang harus dilindungi dan meskipun anak tersebut adalah anak luar kawin, keluarga tetap harus melindungi dan mengakui karena ia adalah darah daging dan bagian keluarga yang tak dapat dipisahkan.

Selain aborsi dan membuang anak, ada juga masyarakat yang melakukan free sex dan memilih untuk menikah siri agar dapat menutupi anak yang lahir sebagai aib sehingga anak tersebut dianggap anak sah oleh negara, agama, serta masyarakat. Padahal, anak hasil perkawinan siri juga termasuk anak luar kawin karena perkawinan siri tidak diakui di Indonesia. Perkawinan siri juga sering dilakukan dengan alas an karena belum siap secara ekonomi untuk melangsungkan perkawinan, sehingga tidak memerlukan banyak uang untuk melangsungkan perkawinan. Perkawinan siri biasanya dilakukan oleh seorang suami yang tidak mendapat ijin dari istrinya untuk melakukan perkawinan lagi ataupun seorang suami yang menceraikan suaminya tetapi masih dalam proses persidangan sehingga secara hukum laki-laki tersebut belum boleh menikah. 
Di Indonesia, ada dua jenis anak luar kawin, yaitu anak luar kawin yang diakui secara sah dan anak luar kawin yang tidak diakui. Anak luar kawin yang diakui dengan sah ialah anak yang dibenihkan oleh suami atau istri dengan orang lain yang bukan istri atau suaminya yang sah. ${ }^{2}$ Anak luar kawin ini harus mendapat pengakuan yang sah, atau ia dianggap tidak ada. Sedangkan anak luar kawin tidak diakui adalah anak luar kawin yang tidak mendapat pengakuan yang sah dari kedua orang tuanya, seperti anak buangan, atau yang mendapat pengakuan kedua orang tuanya tetapi tidak disahkan.

Meskipun demikian, di lingkungan masyarakat terdapat anggapan anak luar kawin merupakan anak haram yang buruk dan lebih baik dihindari atau dibuang karena merupakan anak dari pasangan bukan suami istri yang sah secara hukum. Keluarga juga menganggap anak luar kawin sebagai aib yang harus segera disingkirkan. Hal ini menjadikan beberapa hak anak luar kawin tidak terpenuhi. Begitupula dengan anak hasil perkawinan siri yang dianggap tidak pantas hidup karena mayoritas perkawinan siri dilakukan oleh orang yang berstatus suami dengan selingkuhannya untuk menghalalkan suatu hubungan yang mana istri sah si suami tidak menyetujui perkawinan tersebut berlangsung. Anak dari perkawinan siri juga dikucilkan masyarakat karena dianggap sebagai alasan retak dan hancurnya hubungan rumah tangga orang lain sehingga ia dibenci oleh masyarakat.

Bagi sebuah pernikahan yang dilakukan oleh laki-laki dan wanita yang keduanya sama-sama berstatus lajang, namun sebelumnya telah melakukan hubungan suami istri, maka masyarakat memandang anak dari perkawinan tersebut sebagai anak luar kawin hasil seks bebas dimana ibunya hamil diluar nikah sehingga ayahnya terpaksa menikahi ibunya secara siri untuk menutupi aib kehamilannya. Anak hasil perkawinan siri juga seringkali dikucilkan oleh keluarga

\footnotetext{
${ }^{2}$ Effendi Perangin, Hukum Waris, 12th ed. (Jakarta: Raja Grafindo Persada, 2014). Hlm. 63
} 
kedua orang tuanya karena biasanya perkawinan siri terjadi tanpa persetujuan pihak keluarga, atau dengan persetujuan yang terpaksa.

Dalam persoalan waris, pada umumnya peristiwa pewarisan terjadi antara orang tua dengan anak yang lahir dari perkawinan yang sah sehingga masalah pewarisan yang terjadi hanya dengan anggota keluarga inti saja, namun seiring berkembangnya masyarakat, peristiwa pewarisan juga semakin bervariasi, seperti warisan dari anak jatuh ke orang tua, saudara, pamannya, bahkan jatuh pada orang lain sebagai wasiat. Dengan lahirnya anak luar kawin, khususnya anak dari perkawinan siri, maka harta warisan pun menjadi rumit karena anak luar kawin juga berhak atas harta tersebut.

Di Indonesia terdapat beberapa jenis hukum waris yang diberlakukan dalam praktik kehidupan bermasyarakat, seperti hukum waris perdata yang diatur dalam Kitab Undang-Undang Hukum Perdata (KUHPer) buku II tentang kebendaan dan berlaku bagi masyarakat pada umumnya. Kedua, hukum waris Islam yang diatur dalam Al-Qur'an, Hadist, serta Kompilasi Hukum Islam (KHI) buku II tentang hukum kewarisan. Ketiga, hukum waris adat yang merupakan hukum waris yang berlaku bagi masyarakat daerah yang masih memegang adat.

Meskipun memiliki persamaan dan perbedaan, masyarakat bebas memilih sendiri hukum mana yang ingin diberlakukan untuk melakukan suatu pewarisan dan menyelesaikan masalah pewarisan tersebut, meskipun pada parktiknya juga sering menimbulkan ketidakstabilan hukum dikarenakan hukum yang digunakan masyarakat yang satu berbeda dengan masyarakat yang lainnya.

Bagi status waris anak di luar nilah atau anak hasil perkawinan siri, praktiknya banyak masyarakat yang tidak tahu boleh tidaknya memberikan harta warisnya kepada anak dari perkawinan siri dan bahkan terkadang diperlakukan selayaknya anak sah, karena memang anak tersebut sah secara agama sehingga seluruh warisan akan diberikan kepadanya yang akhirnya menyulut kemarahan ahli waris lainnya, namun ketika terjadi sengketa di pengadilan, ia dinyatakan 
hanya mendapat sebagian kecil harta atau tidak mendapat apapun karena kedudukannya yang lemah di dalam hukum positif di Indonesia.

Banyak pula anak hasil perkawinan siri yang tidak disahkan dan kedua orang tuanya juga tidak melakukan itsbat nikah hingga anak tersebut dewasa dan orang tuanya meninggal. Akibatnya, anak tersebut tidak memiliki hubungan perdata dan hubungan apapun dengan orang tuanya, terutama ayahnya. Anak hasil perkawinan siri juga sering mendapat diskriminasi dari pihak keluarganya sendiri ketika pewarisan terjadi, seperti pengurangan harta warisan dari yang seharusnya diberikan kepadanya, meskipun kedua orang tuanya telah mengakui anak tersebut ataupun telah melakukan itsbat nikah sehingga anaknya menjadi anak sah. Hal ini tentu tidak sesuai dengan aturan hukum waris yang berlaku di Indonesia.

Berdasarkan penjelasan tersebut, dengan mempertimbangkan banyaknya timbul permasalahan atau sengketa tentang pewarisan kepada anak luar kawin hasil perkawinan siri, maka penting sekali kejelasan dan perlindungan hukum untuk anak luar kawin, khususnya hasil perkawinan siri sebagai ahli waris di Indonesia agar anak tersebut tidak mendapat diskriminasi dari berbagai pihak. Selain itu, hak dan kewajiban anak tersebut bisa terpenuhi secara maksimal, serta untuk mempertegas bahwa anak luar kawin juga diakui dan dilindungi oleh hukum yang berlaku di Indonesia seperti halnya anak sah, anak tiri maupun anak angkat.

Penelitian yang membahas tentang anak hasil perkawinan siri sebagai ahli waris sudah cukup banyak dilakukan oleh para peneliti terdahulu. Berdasarkan hasil penelusuran terhadap beberapa literatur yang telah dilakukan, maka setidaknya ditemukan beberapa literatur yang membahas mengenai permasalahan ini.

Pertama, Erni Agustina dengan judul Akibat Hukum Hak Mewaris Anak Hasil Perkawinan Siri Berbasis Nilai Keadilan pada tahun 2015 yang dalam penelitiannya tersebut membahas tentang perkawinan siri atau perkawinan di bawah tangan yang masih terjadi di Indonesia dan belum memberikan kepastian hukum bagi suami, istri, dan anak hasil perkawinan. Anak hasil perkawinan yang 
sah akan mendapatkan hak-haknya, termasuk hak waris. Berbeda dengan anak dari hasil perkawinan siri yang dicatatkan sebagai anak luar kawin. Hal tersebut berdampak pada status anak yang tidak bisa memperoleh hak-haknya khususnya hak waris. $^{3}$

Adapun hsil penelitian ini menjelaskan bahwa menurut Undang-Undang Nomor 1 Tahun 1974 dan KHI bahwa anak yang dilahirkan dari nikah siri atau perkawinan di bawah tangan dianggap sebagai anak tidak sah atau anak luar nikah, sebagai konsekuensinya maka anak hanya mempunyai hubungan perdata dengan ibu dan keluarga ibunya. Dengan demikian, anak tidak berhak atas biaya kehidupan, pendidikan, nafkah, dan hak waris dari ayahnya. Putusan MK Nomor : 46/PUUVIII/2010 telah memberikan kejelasan terhadap status hukum anak nikah siri, yakni anak yang dilahirkan di luar perkawinan mempunyai hubungan perdata dengan ibunya dan keluarga ibunya serta dengan laki-laki sebagai ayahnya yang dapat dibuktikan berdasarkan ilmu pengetahuan dan teknologi dan/atau alat bukti lain menurut hukum mempunyai hubungan darah, termasuk hubungan perdata dengan keluarga ayahnya. Dengan Putusan Mahkamah Konstitusi tersebut, maka anak mendapatkan hak waris dari ayah biologis yang mengakuinya setelah dilakukan pembuktian. Putusan Mahkamah Konstitusi memberikan kepastian, keadilan, dan perlindungan hukum atas status atau kedudukan serta hak-haknya. ${ }^{4}$

Kedua, Fitria Olivia dengan judul Akibat Hukum Terhadap Anak Hasil Perkawinan Siri Pasca Putusan Mahkamah Konstitusi pada tahun 2014 yang dalam penelitiannya tersebut membahas tentang kedudukan hukum nikah siri dilihat dari Undang-Undang Nomor 1 tahun 1974 dan akibat hukum terhadap anak

\footnotetext{
${ }^{3}$ Erni Agustina, "Akibat Hukum Hak Mewaris Anak Hasil Perkawinan Siri Berbasis Nilai Keadilan," Jurnal Pembaruan Hukum 2, no. 2 (2015). Hlm. 382

${ }^{4}$ Agustina. Hlm. 389
} 
hasil perkawinan siri ditinjau menurut Undang-Undang Nomor 1 Tahun 1974 pasca putusan Mahkamah Konstitusi Nomor 46/PUU-VIII/2010. ${ }^{5}$

Hasil penelitian tersebut menjelaskan bahwa Undang-Undang Nomor 1 Tahun 1974 tentang perkawinan menyatakan bahwa perkawinan itu dikatakan sah jika di catatkan sesuai dengan ketentuan Pasal 2 ayat (2), oleh karena itu nikah siri di anggap tidak sah karena tidak memenuhi unsure pasal tersebut. Menurut Hukum Islam Nikah siri itu dikatakan sah jika telah memenuhi syarat sahnya perkawinan dan dilaksanakan menurut hukum masing-masing agama dan kepercayaannya, hal ini berdasarkan Pasal 2 ayat (1) Undang-Undang Nomor 1 Tahun 1974 dan Pasal 4 Kompilasi Hukum Islam. Atau dengan kata lain perkawinan sah menurut hukum islam apabila memenuhi syarat dan rukun nikah.

Sebelum adanya putusan MK No 46/PUU-VIII/2010, anak dari hasil nikah siri hanya mempunyai hubungan keperdataan dengan ibunya dan keluwarga ibunya. Sedangkan setelah adanya putusan MK No 46/PUU-VIII/2010, anak dari hasil nikah siri tidak hanya memiliki hubungan perdata dengan ibu dan keluawarga ibunya, akan tetapi dapat pula memiliki hubungan keperdataan dengan ayahnya jika mendapat pengakuan dari ayah biologisnya atau dapat di buktikan dengan ilmu pengetahuan dan teknologi. Putusan Mahkamah Konstitusi mengabulkan permohonan pemohon yang mengandung cacat hukum. Kasus yang didalilkan Pemohon adalah kasus anak yang lahir sebagai akibat dari poligami di bawah tangan yang menurut hukum yang berlaku masih dimungkinkan mendapatkan jaminan hukum, sedangkan yang dimohonkan adalah me-review ketentuan Pasal 2 ayat (2) juga ketentuan Pasal 43 ayat (1) Undang-Undang Nomor 1 Tahun 1974 tentang status hukum anak yang lahir di luar perkawinan. ${ }^{6}$

5 Fitria Olivia, "Akibat Hukum Terhadap Anak Hasil Perkawinan Siri Pasca Putusan Mahkamah Konstitusi,” Lex Jurnalica 11, no. 1 (2014). Hlm. 132

${ }^{6}$ Olivia. Hlm. 140 
Putusan Mahkamah Konstitusi menganalogikan anak yang lahir sebagai akibat dari poligami di bawah tangan dengan anak yang lahir di luar perkawinan, padahal kedua status anak ini berada pada dua substansi yang berlainan menurut hukum. Pasal 43 ayat (1) Undang-undang Nomor 1 Tahun 1974 yang senada dengan Pasal 100 Kompilasi Hukum Islam, substansinya tidak bertentangan dan atau sebenarnya sejalan dengan Pasal 28 B ayat (1) dan ayat (2) UndangUndang Dasar 1945 juga sejalan dengan Syari'at Islam. Putusan Mahkamah Konstitusi bertentangan terutama dengan Pasal 28 B ayat (1) UUD 45 dan bertentangan dengan Syari'at Islam. Oleh karena itu putusan MK ini akan mengundang polemik dalam masyarakat muslim yang berkepanjangan. Putusan Mahkamah Konstitusi melahirkan ketentuan normatif yang tidak mendorong untuk terciptanya suasana masyarakat yang tertib dan ta'at hukum, melainkan berupaya melegalisasikan suatu akibat dari perbuatan yang melanggar hukum. Pasal 43 ayat (1) yang telah direview oleh putusam Makhama Konstitusi hanya berlaku dalam hubungan hukum keperdataan antara anak dengan ayah biologisnya, selain hubungan keperdataan perwalian dalam perkawinan dan selain hubungan keperdataan dalam kewarisan. ${ }^{7}$

Mencermati dua penelitian terdahulu di atas, maka dapat dikatakan penelitian ini berbeda dengan penelitian tersebut, adapun unsur kebaruan dalam penelitian ini terletak pada kajian isu hukum masing-masing penelitian, yang dalam kajian ini membahas tentang kedudukan anak hasil perkawinan siri menurut konstitusi yang berlaku di Indonesia serta kedudukan hukum anak luar kawin hasil perkawinan siri sebagai ahli waris menurut hukum perdata dan hukum Islam.

\footnotetext{
${ }^{7}$ Olivia. Hlm. 141
} 


\section{Rumusan Masalah}

Berdasarkan pemaparan dari latar belakang masalah di atas, maka yang menjadi batasan masalah dalam penelitian ini yaitu bagaimana kedudukan anak hasil perkawinan siri menurut konstitusi yang berlaku di Indonesia serta bagaimana kedudukan hukum anak luar kawin hasil perkawinan siri sebagai ahli waris menurut hukum perdata dan hukum Islam.

\section{Tujuan Penelitian}

Tujuan penelitian ini adalah untuk mengkaji secara mendalam kedudukan anak hasil perkawinan siri menurut konstitusi yang berlaku di Indonesia serta menganalisa kedudukan hukum anak luar kawin hasil perkawinan siri sebagai ahli waris menurut hukum perdata dan hukum Islam.

\section{Metode Penelitian}

Jenis penelitian yang digunakan dalam kajian ini adalah penelitian yuridis normatif yaitu dengan mengkaji ketentuan perundang-undangan yang berlaku. Penelitian normatif berfungsi untuk memberi argumentasi yuridis ketika terjadi kekosongan, kekaburan, dan konflik norma hukum. ${ }^{8}$ Kemudian untuk pendekatan yang digunakan adalah pendekatan Undang-Undang (statue approach) dan pendekatan komparatif (comparative approach) dimana lebih menekankan kepada peraturan-peraturan yang ada. Penelitian ini menggunakan bahan hukum kepustakaan yang dapat berupa Peraturan perundang-undangan, dokumen, bukubuku, laporan, arsip, dan literatur yang berkaitan dengan masalah yang diteliti.

Bahan hukum yang akan digunakan dalam penelitian ini adalah: (1). Bahan hukum primer, yaitu bahan-bahan hukum pokok yang mengikat. Dalam penulisan ini, digunakan bahan hukum primer berupa Undang-Undang Dasar Negara Republik Indonesia Tahun 1945, Kitab Undang-Undang Hukum Perdata, Undang-

\footnotetext{
${ }^{8}$ I Made Pasek Diantha, Metodologi Penelitian Hukum Normatif Dalam Justifikasi Teori Hukum (Jakarta: Prenada Media Group, 2017). Hlm. 12
} 
Undang Nomor 1 Tahun 1974 tentang Perkawinan, Undang-Undang Nomor 23 Tahun 2002 tentang Perlindungan Anak, Undang-Undang Nomor 35 Tahun 2014 tentang Perubahan Atas Undang-Undang Nomor 23 Tahun 2002 tentang Perlindungan Anak, Undang-Undang Nomor 39 Tahun 1999 tentang Hak Asasi Manusia serta Inpres Nomor 1 Tahun 1991 tentang Kompilasi Hukum Islam. (2). Bahan hukum sekunder, yaitu bahan-bahan hukum yang mendukung dan memperjelas bahan hukum primer yang berupa dokumen-dokumen resmi, meliputi karya tulis, buku-buku teks, jurnal-jurnal hukum dan komentar-komentar atas putusan pengadilan. (3). Bahan non-hukum, yaitu bahan yang memberikan penjelasan maupun petunjuk terhadap bahan hukum primer maupun sekunder yang telah ada seperti Kamus Besar Bahasa Indonesia dan lain sebagainya yang digunakan untuk mencari istilah-istilah dalam rangka menjelaskan hal-hal yang digunakan dalam bahan hukum primer maupun bahan hukum sekunder.

Teknik Pengumpulan data yang akan digunakan dalam penelitian hukum ini adalah studi kepustakaan yang terbatas pada penggunaan dokumen dan bahan pustaka. Pengumpulan data dilakukan dengan cara mengumpulkan data-data tertulis yang berkaitan dengan masalah yang diteliti.

Metode yang digunakan untuk menganalisis dan mengolah data-data yang terkumpul adalah metode deskriptif kualitatif. Maksud dari penggunaan metode tersebut adalah memberikan gambaran terhadap pemasalahan berdasarkan pada pendekatan yuridis normatif. ${ }^{9}$

\footnotetext{
9 Ade Saptomo, Pokok-Pokok Metodologi Penelitian Hukum (Surabaya: Unesa University Press, 2007). Hlm. 30
} 


\section{Hasil Penelitian dan Pembahasan}

5.1. Kedudukan Anak Hasil Perkawinan Siri Menurut Konstitusi yang Berlaku di Indonesia

Salah satu bentuk perlindungan terhadap anak adalah dengan adanya pemberian identitas terhadap anak. Pencatatan kelahiran anak menghasilkan Akta Kelahiran Anak yang merupakan dokumen resmi dan bertujuan untuk mewujudkan kepastian hukum bagi seorang anak, hal tersebut peniting karena:

5.1.1. Pencatatan kelahiran anak memastikan secara tegas tentang adanya pengakuan negara terhadap keberadaan anak sebagai subyek hukum. Ini berarti bahwa pencatatan kelahiran anak tersebut menjelaskan identitas yuridis seorang anak karena memuat nama anak, nama kedua orang tuanya, tempat dan tanggal lahir, yang diakui/disahkan oleh pejabat berwenang untuk itu

5.1.2. Pencatatan kelahiran anak memastikan perlindungan hukum atas hak-hak seseorang (anak). Ini berarti bahwa pencatatan kelahiran anak memberi dasar hukum bagi pemerintah dalam memberi perlindungan hak-hak anak. ${ }^{10}$

Berdasarkan ketentuan dalam Pasal 27 Undang-Undang Nomor 23 Tahun 2002 tentang Perlindungan Anak, dapat diketahui bahwa identitas seorang anak harus diberikan sejak kelahirannya dan dituangkan dalam akta kelahiran. Berdasarkan pasal ini, dapat juga diketahui bahwa pencatatan kelahiran anak tidak saja dapat dilakukan terhadap anak sah, tetapi juga anak luar kawin bahkan anak yang proses kelahirannya tidak diketahui keberadaanya. Hal ini mengindikasikan bahwa anak jalanan atau gepeng (geladangan, pengemis) dapat dicatatkan kelahirannya.

\footnotetext{
${ }^{10}$ Maidin Gultom, Perlindungan Hukum Terhadap Anak Dan Perempuan (Bandung: Refika Aditama, n.d.). hlm. 106
} 
Meskipun demikian ada yang berbeda untuk anak hasil perkawinan siri. Perkawinan siri merupakan perkawinan yang sah menurut Hukum Islam, tetapi menurut hukum perdata menjadi tidak sah karena tidak dicatatkan. Perkawinan yang tidak dicatatkan akan dianggap tidak pernah terjadi.

Karena hal tersebut, kedudukan anak hasil perkawinan siri sama dengan anak luar kawin. Pencatatan identitas anak hasil perkawinan siri tersebut hanya mencantumkan nama ibu saja tanpa adanya identitas dari ayah karena ia hanya memiliki hubungan perdata dengan ibunya saja. Agar anak hasil perkawinan siri bisa mendapatkan haknya secara keseluruhan, maka diperlukan adanya suatu pengakuan sesuai Pasal 280 KUH Perdata:

"Dengan pengakuan terhadap anak diluar kawin terlahirlah hubungan perdata antara anak itu dengan ayah atau ibunya". ${ }^{11}$

Artinya bahwa seorang anak luar kawin khususnya anak hasil perkawinan siri baru memiliki hubungan perdata baik dengan ayah maupun ibunya setelah ada pengakuan terhadap anak tersebut, bukan serta-merta terjadi dengan sendirinya. Karena hal tersebut maka seorang anak hasil perkawinan siri, meskipun memiliki ayah dan ibu biologis tetapi secara yuridis anak tersebut dianggap tidak memiliki ayah maupun ibu. Sehingga ayah atau ibu anak tersebut tidak memiliki hak maupun kewajiban di hadapan hukum kepada anak dari perkawinan sirinya. Tanpa adanya pengakuan tidak akan ada hubungan perdata antara si anak dengan ayah maupun ibunya. Hal ini berbeda dengan hukum Islam dimana hubungan perdata antara anak hasil perkawinan siri dengan ibunya terjadi secara langsung ketika anak tersebut dilahirkan. Hal ini juga tercantum dalam Pasal 43 Ayat (1) Undang-Undang Nomor 1 Tahun 1974 tentang Perkawinan yang menyatakan:

"Anak yang dilahirkan diluar perkawinan hanya mempunyai hubungan perdata dengan ibunya dan keluarga ibunya."

\footnotetext{
${ }^{11}$ Pasal 280 Kitab Undang-Undang Hukum Perdata

${ }^{12}$ Pasal 43 Ayat (1) Undang-Undang Nomor 1 Tahun 1974 tentang Perkawinan
} 
Perkawinan orang tuanya yang tidak memenuhi norma hukum sebagaimana diatur dalam Pasal 2 Ayat (2) Undang-Undang Nomor 1 Tahun 1974 tentang Perkawinan yakni tidak dicatatkan menurut Undang-Undang yang berlaku, maka secara yuridis anak yang dilahirkan dari perkawinan tersebut tidak dilindungi oleh hukum (no legal protecs). Sehingga bila seorang anak yang dilahirkan itu memerlukan akta kelahiran untuk suatu kepentingan seperti persyaratan memasuki suatu perguruan (sekolah) misalnya, tidak dicantumkan nama bapaknya, karena orang tuanya tidak memiliki bukti tentang perkawinan berupa akta nikah, sebab dasar untuk menerbitkan akta kelahiran anak adalah akta nikah orang tuanya. ${ }^{13}$

Secara yuridis keberadaan anak dari perkawinan siri tersebut tetap mendapat pengakuan, perlindungan /dan kepastian hukum yang ada serta perlakuan yang sama di hadapan hukum, sebagaimana ketentuan Pasal 28D Ayat (1) Undang-Undang Dasar RI Tahun 1945, karena ia warga Negara Indonesia. Ketidaksamaan perlindungan hukum yang diberikan Negara kepada anak tersebut, seperti hak menuntut warisan dari harta peninggalan bapaknya, oleh karena hubungan hukum antara anak dengan bapak kandungnya tidak didukung oleh bukti yang otentik berupa akta nikah orang tuanya, maka secara formil ia tidak dapat mengajukan gugatan waris melalui lembaga formal Negara yakni lembaga peradilan. Namun ia tetap berhak menuntut hak warisnya melalui jalur tidak formil, umpamanya melalui jalur musyawarah kekeluargaan atau desa. ${ }^{14}$

Anak sah dan anak luar kawin yang diakui sama-sama memiliki hak terhadap harta peninggalan orang tuanya, mereka juga sama-sama memiliki hak saissane, hak hereditas petitio dan hak untuk menuntut pemecahan warisan. Namun sesungguhnya mereka memiliki perbedaan, antara lain anak-

13 M Anshary, Kedudukan Anak Dalam Perspektif Hukum Islam Dan Hukum Nasional (Bandung: Mandar Maju, n.d.). hlm. 142

${ }^{14}$ M. Anshary, Op. Cit, hlm. 144. 
anak luar kawin meskipun telah diakui tidak berada dibawah kekuasaan orang tua melainkan hanya dibawah perwalian, hak bagian waris mereka berbeda dengan hak yang dimiliki anak sah dan mereka tidak memiliki hubungan hukum apa-apa selain dengan orang tua yang mengakuinya saja. ${ }^{15}$ Seorang anak luar kawin yang tidak diakui oleh orang tuanya hanya berhak atas nafkah ataupun shodaqoh sebagai bentuk tanggung jawab orang tua terhadap anak. Hal ini tentu menjadi perdebatan karena sesungguhnya anak hasil perkawinan siri merupakan anak sah dan tidak boleh disamakan dengan anak luar kawin.

Seperti kasus hak anak hasil perkawinan siri yang diajukan oleh $\mathrm{Hj}$. Aisyah Mochtar alias Machica binti H. Mochtar Ibrahim dan Muhammad Iqbal Ramadhan bin Moerdiono yang menandai lahirnya paradigma hukum baru bagi anak yang lahir dari perkawinan siri. Kasus ini dilatar belakangi karena Machica menikah siri dengan Moerdiono pada 20 Desember 1993 hingga memiliki seorang anak, yaitu Muhammad Iqbal Ramadhan. Machica bercerai dengan suaminya pada tahun 1998. Karena perkawinan tersebut dilakukan secara siri, maka negara tidak mengakui adanya perkawinan tersebut. Moerdiono juga tak mengakui anak dari perkawinan sirinya tersebut. Untuk memperjuangkan hak anaknya, Machica melayangkan permohonan uji materiil (judical review) ke Mahkamah Konstitusi terkait Pasal 2 Ayat (2) dan Pasal 43 Ayat (1) Undang-Undang Nomor 1 Tahun 1974 Tentang Perkawinan.

Pemohon merupakan pihak yang secara langsung mengalami dan merasakan hak konstitusionalnya dirugikan dengan diundangkannya UndangUndang Nomor 1 Tahun 1974 tentang Perkawinan terutama berkaitan dengan Pasal 2 ayat (2) dan Pasal 43 ayat (1). Pasal ini ternyata justru menimbulkan ketidakpastian hukum yang mengakibatkan kerugian bagi Pemohon berkaitan

${ }^{15}$ Hartono Suryopratikno, Hukum Waris Tanpa Wasiat (Yogyakarta: Seksi Notariat Fakultas Hukum Universitas Gadjah Mada, 1982). Hlm. 39 
dengan status perkawinan dan status hukum anaknya yang dihasilkan dari hasil perkawinan.

Setelah melewati serangkaian pemeriksaan, Mahkamah Konstitusi memutuskan bahwa Pasal 43 ayat (1) Undang-Undang Nomor 1 Tahun 1974 tentang Perkawinan (Lembaran Negara Republik Indonesia Tahun 1974 Nomor 1, Tambahan Lembaran Negara Republik Indonesia Nomor 3019) yang menyatakan:

"Anak yang dilahirkan di luar perkawinan hanya mempunyai hubungan perdata dengan ibunya dan keluarga ibunya". 16

Tidak memiliki kekuatan hukum yang mengikat sepanjang dimaknai menghilangkan hubungan perdata dengan laki-laki yang dapat dibuktikan berdasarkan ilmu pengetahuan dan teknologi dan / atau alat bukti lain menurut hukum ternyata mempunyai hubungan darah sebagai ayahnya, sehingga ayat tersebut harus dibaca:

"Anak yang dilahirkan di luar perkawinan mempunyai hubungan perdata dengan ibunya dan keluarga ibunya serta dengan laki-laki sebagai ayahnya yang dapat dibuktikan berdasarkan ilmu pengetahuan dan teknologi dan/atau alat bukti lain menurut hukum mempunyai hubungan darah, termasuk hubungan perdata dengan keluarga ayahnya".

Dengan demikian Mahkamah Konstitusi mengabulkan permohonan dari para pemohon. Mohammad Iqbal Ramadhan dinyatakan memiliki hubungan perdata dengan ayahnya. Statusnya yang sebelumnya anak luar kawin juga berubah menjadi anak sah meskipun ia lahir sebagai anak dari perkawinan siri.

${ }^{16}$ Pasal 43 ayat (1) Undang-Undang Nomor 1 Tahun 1974 tentang Perkawinan (Lembaran Negara Republik Indonesia Tahun 1974 Nomor 1, Tambahan Lembaran Negara Republik Indonesia Nomor 3019). 


\subsection{Pewarisan Anak Hasil Perkawinan Siri Ditinjau dari Hukum Perdata}

Dalam hukum waris barat, anak luar kawin dapat dibedakan menjadi dua macam, yaitu anak luar kawin yang diakui dan anak luar kawin yang disahkan. Anak yang disahkan memiliki kedudukan yang berbeda dengan anak yang hanya diakui. Anak yang diakui tetap memiliki kedudukan sebagai anak luar kawin, meskipun secara hukum ia memiliki hak yang hampir sama dengan anak sah. Seorang anak luar kawin dapat diakui sebelum terjadinya perkawinan yang sah antara salah satu orang tuanya dengan orang lain yang bukan orang tuanya, dan keberadaan anak tersebut tidak mengganggu perkawinan orang tuanya dan orang lain itu. Bagian warisan anak semacam ini adalah $1 / 3$ bagiannya apabila ia anak sah, jika mewaris bersama golongan 1 , yaitu anak sah, maupun istri sah orang tuanya. Lalu $1 / 2$ bagian apabila ia mewaris bersama golongan II dan III yakni kakeknya, paman dan bibi, maupun buyut anak tersebut, serta $3 / 4$ bagian apabila ia mewaris bersama golongan IV, yaitu orang dengan kerabat yang lebih jauh dari orang tuanya yang menjadi pewaris.

Pada dasarnya anak dari hasil perkawinan siri dapat dikategorikan dalam anak yang disahkan karena ayah biologisnya menikahi ibu biologisnya secara agama sehingga seharusnya bagian warisnya pun disamakan dengan anak dari perkawinan yang sah. Pembagian warisan anak sah adalah sama rata, yaitu satu banding satu. Anak sah merupakan golongan I dan memiliki sifat menutup golongan yang lebih jauh. Kedudukan anak dari perkawinan siri ini sebagai anak yang disahkan dipatahkan dengan adanya keharusan mencatatkan pernikahan baru dia bisa diakui Negara sebagai anak sah sebagaimana diatur dalam undang-undang nomor 1 tahun 1974, sehingga berlakulah asas lex specialis derogate legi generalis. 


\subsection{Pewarisan Anak Hasil Perkawinan Siri Ditinjau dari Hukum Islam}

Dalam sistem hukum Islam, perkara waris memiliki kedudukan yang sangat penting dikarenakan terkait timbul dan lenyapnya hak dan kewajiban seseorang terhadap suatu harta peninggalan yang apabila tidak terselesaikan dengan baik tidak jarang menimbulkan adanya konflik panjang dalang sebuah keluarga. Pewarisan hukum Islam sangat berbeda dengan hukum perdata yang dalam Pasal 833 KUH Perdata bahwa ahli waris tidak hanya mewarisi harta si pewaris saja, melainkan juga seluruh utang-piutangnya, sedangkan dalam hukum Islam, suatu harta peninggalan diperuntukkan bagi biaya perawatan, utang-piutang, wasiat dan waris itu sendiri. ${ }^{17}$

Dalam pandangan kedua hukum tersebut terdapat perbedaan yang mencolok. Pengertian hubungan perdata antara anak dan ayah biologisnya sangatlah berbeda. Dalam perspektif Hukum Islam, dibedakan antara hubungan nasab dan hubungan perdata. Kata nasab (bhs. Arab) secara harfiah (ethimologi) berarti keturunan, pertalian darah, persaudaraan. ${ }^{18}$ Secara istilah (therminologi) diartikan sebagai hubungan kekerabatan antara seorang dengan orang lain karena pertalian darah dan keturunan. Sebagai akibat dari adanya hubungan nasab, maka timbulah hak dan kewajiban antara orang yang mempunyai hubungan nasab tersebut yang mencakup hak-hak nasab dan hakhak keperdataan.

Hak-hak nasab, seperti hak saling mewarisi, hak menjadi wali nikah terhadap seorang anak perempuan ketika melangsungkan aqad nikah, hak seorang anak untuk menggunakan nama bapaknya sebagai bin atau binti

17 Adapun yang dimaksud dengan biaya perawatan adalah biaya-biaya yang diperuntukkan mulai dari saat meninggalnya si mati sampai dengan penguburannya. Itu mencangkup biaya untuk memandikan, mengkafani, mengusung, dan menguburkan si mati. Biaya perawatan haris wajar, tidak berlebih-lebih dan tidak sangat kurang. Yang dimaksud dengan utang mencangkup kewajibankewajiban terhadap Allah, seperti zakat, pergi haji, pembayaran kafarah, dan lain-lain serta kewajibankewajiban terhadap sesama manusia.

${ }^{18}$ Tim Prima Pena, Kamus Ilmiah Populer (Jakarta: Gitamedia Press, 2006). Hlm. 332 
dibelakang namanya. Hak-hak nasab semacam ini tidak dapat dilakukan oleh orang yang tidak mempunyai hubungan nasab.

Adapun hubungan perdata digunakan hanya terbatas pada hal-hal yang berkaitan dengan kepentingan si anak yang merupakan tugas orang tua dalam bidang kesejahteraan, biaya pendidikan, nafkah, perawatan dan pengasugan atau pemeliharaan anak. Tugas-tugas tersebut dapat dialihkan dari orang yang mempunyai hubungan nasab/pertalian darah kepada orang lain. Dalam kasus pengangkatan anak misalnya, masalah nasab tidak boleh berubah, seperti wali nikah, hak saling mewaris dan pemakai nama bapak (bin atau binti tidak boleh seorang anak dinisbahkan kepada orang lain yang bukan bapaknya. Adapun masalah keperdataan, seperti perawatan, nafkag hidup, biaya pendidikan anak, dan lain-lain, seorang anak angkat dapaat memperoleh dari siapa saja yang bersedia menjadikannya sebagai anak angkat. Jadi, keperdataan tidak mencakup di dalamnya hubungan nasab. ${ }^{19}$

Pembagian warisan dalam hukum perdata maupun hukum Islam disamakan dengan anak sah. Meskipun demikian, kedua bagiannya tetaplah berbeda. Pembagian warisan dalam hukum perdata didasarkan pada golongangolongan yang berhak menerima warisan berdasarkan derajat dan kerabat, mulai dari yang terdekat hingga terjauh tanpa adanya perbedaan jenis kelamin. Derajat yang lebih dekat dengan pewaris, misalkan anak dapat mewarisi seluruh harta peninggalan pewaris tanpa memperhatikan ahli waris lainnya dengan derajat yang lebih jauh, karena otomatis derajat yang lebih jauh akan tertutup. Hal ini juga berlaku bagi ibu dan bapak pewaris yang berada dalam golongan II.

Dalam kasus anak luar kawin yang didapatkan dari perkawinan siri, Hukum Islam meletakkan status anak tersebut seimbang dengan anak sah, karena perkawinan siri merupakan perkawinan yang disahkan secara Islam

\footnotetext{
${ }^{19}$ M. Anshary, Op.Cit hlm. 94.
} 
dan telah memenuhi rukun maupun syarat sah diberlakukannya suatu perkawinan. Oleh sebab itu, anak luar kawin dari perkawinan siri berhak memperoleh bagian harta warisan dari pihak ibu maupun ayahnya sesuai ketentuan yang berlaku.

Adapun ketentuan pembagian warisan bagi anak luar kawin yang didapatkan dari perkawinan siri dalam hukum Islam akan dibahas lebih lanjut sebagai berikut :

\subsubsection{Ahli Waris Anak Perempuan}

Ahli waris anak perempuan baik satu orang atau lebih, disebut ahli waris dzawil furudh, hal ini karena bagian warisan mereka telah ditentukan dalam nash Al Qur'an. Bagian warisan dari anak perempuan ada terbagi menjadi dua macam, yaitu (1) apabila hanya ada seorang anak perempuan, maka ia mewarisi $1 / 2$ harta peninggalan. (2) apabila ada beberapa anak perempuan maka ia mewarisi $2 / 3$ dari harta peninggalan.

\subsubsection{Ahli Waris Anak Laki-Laki}

Jika yang mewaris itu hanya anak laki-laki saja, maka mereka disebut ashabah binafsih, yakni ahli waris yang menghabiskan sisa harta setelah diambil untuk bagian ahli waris dzawil furudh, bila ada. Seperti suami atau istri dari pewaris, ayah si pewaris, atau ibunya, atau kakeknya. Dalam hal ini, bagian warisan pewaris lainnya dihitung terlebih dahulu, barulah sisanya diberikan kepada anak laki-laki karena mereka berhak mewaris seluruh sisa harta.

Namun, apabila si mati meninggalkan anak laki-laki lebih dari seorang, sedangkan ahli waris lain tidak ada, maka dalam keadaan seperti ini harta warisan dibagi rata kepada anak lakilaki. Namun, apabila si mati hanya meninggalkan seorang anak 
laki-laki maka seorang anak laki-laki tersebut menjadi ashobah. Dengan demikian seluruh harta waris menjadi haknya. ${ }^{20}$

\subsubsection{Ahli Waris Anak Laki-Laki dan Perempuan}

Jika ahli waris anak perempuaan itu mewaris bersama anak lakilaki, maka mereka disebut ahli waris ashabah bil ghair, artinya mereka menghabiskan sisa harta bersama anak laki-laki, karena mereka mewaris bergabung bersama anak laki-laki. Dalam hal ini, ditentukan bahwa bagian warisan anak laki-laki adalah dua kali anak perempuan.

Meskipun anak hasil perkawinan siri dihitung anak sah menurut hukum Islam, namun kelemahan yang terdapat dalam praktik waris seperti ini terletak pada tidak adanya kekuatan hukum karena tidak adanya pencatatan di KUA. Oleh karena itu, maka apabila terjadi perselisihan terutama akibat warisan, hanya dapat diselesaikan melalui jalur kekeluargaan.

Untuk melindungi hak-hak anak hasil perkawinan siri, orang tua dapat melakukan itsbat nikah agar pasangan suami istri yang melakukan perkawinan siri akan mendapatkan akta pernikahan dan pernikahannya dianggap sah di depan hukum, begitu juga dengan anaknya yang berstatus anak zina atau anak luar kawin akan berubah menjadi anak sah sehingga dilindungi oleh hukum.

Anak hasil perkawinan siri meskipun lahir dalam suatu perkawinan yang sah menurut hukum Islam, tetapi tetap dipandang sebagai anak yang lahir diluar perkawinan oleh hukum Islam yang diberlakukan di Indonesia. Karena hal tersebut, apabila yang meninggal ayahnya, ia tidak bisa mendapat warisan, namun apabila yang meninggal ibunya, ia berhak atas warisan tersebut.

\footnotetext{
${ }^{20}$ Sudarsono, Hukum Kekeluargaan Nasional (Jakarta: PT. Rineka Cipta, n.d.). hlm. 345
} 


\section{Kesimpulan}

Pewarisan terhadap anak dari hasil perkawinan siri sangat berbeda dalam dua sudut hukum. Meskipun sama-sama dapat mewaris sebagai anak sah, tetapi bagian warisnya berbeda. Dalam hukum perdata, bagian warisnya dibagi rata. Sedangkan dalam hukum Islam, anak hasil perkawinan siri dihitung sebagai anak sah. Bagian anak perempuan adalah $1 / 2$ apabila ia anak satu-satunya, dan $2 / 3$ apabila ada lebih dari satu anak perempuan. Sedangkan bagian anak laki-laki adalah seluruh sisa harta warisan yang telah dibagi dengan ahli waris lainnya. Apabila anak laki-laki mewaris bersama anak perempuan, maka bagian anak lakilaki tersebut adalah dua kali anak perempuan.

Pada dasarnya anak dari hasil perkawinan siri dapat dikategorikan dalam anak yang disahkan karena ayah biologisnya menikahi ibu biologisnya secara agama sehingga seharusnya bagian warisnya pun disamakan dengan anak dari perkawinan yang sah. Pembagian warisan anak sah adalah sama rata, yaitu satu banding satu. Anak sah merupakan golongan I dan memiliki sifat menutup golongan yang lebih jauh. Kedudukan anak dari perkawinan siri ini sebagai anak yang disahkan dipatahkan dengan adanya keharusan mencatatkan pernikahan baru dia bisa diakui Negara sebagai anak sah sebagaimana diatur dalam undangundang nomor 1 tahun 1974, sehingga berlakulah asas lex specialis derogate legi generalis.

Meskipun anak hasil perkawinan siri diakui secara sah dalam hukum Islam dan mendapat bagian yang sama dengan anak sah, tetapi hal ini tidak berlaku di Indonesia. Hukum Islam yang diberlakukan di Indonesia tetap tidak mengakui adanya perkawinan siri, sehingga anak tersebut hanya bisa mewarisi harta ibunya, bukan ayahnya. Apabila ia tetap ingin mewarisi harta ayahnya, bisa tetap dibagi berdasar acauan pembagian yang ada, tetapi apabila ada sengketa hanya bisa diselesaikan melalui jalur kekeluragaan karena anak hasil perkawinan siri juga tidak memiliki kedudukan apapun dalam hukum yang berlaku di Indonesia. 


\section{DAFTAR PUSTAKA}

\section{Buku}

Ade Saptomo. Pokok-Pokok Metodologi Penelitian Hukum. Surabaya: Unesa University Press, 2007.

Sudarsono. Hukum Kekeluargaan Nasional. Jakarta: PT. Rineka Cipta, n.d.

Tim Prima Pena. Kamus Ilmiah Populer. Jakarta: Gitamedia Press, 2006.

Effendi Perangin. Hukum Waris. 12th ed. Jakarta: Raja Grafindo Persada, 2014.

Hartono Suryopratikno. Hukum Waris Tanpa Wasiat. Yogyakarta: Seksi Notariat Fakultas Hukum Universitas Gadjah Mada, 1982.

I Made Pasek Diantha. Metodologi Penelitian Hukum Normatif Dalam Justifikasi Teori Hukum. Jakarta: Prenada Media Group, 2017.

M Anshary. Kedudukan Anak Dalam Perspektif Hukum Islam Dan Hukum Nasional. Bandung: Mandar Maju, n.d.

Maidin Gultom. Perlindungan Hukum Terhadap Anak Dan Perempuan. Bandung: Refika Aditama, n.d.

\section{Artikel Jurnal}

Agustina, Erni. "Akibat Hukum Hak Mewaris Anak Hasil Perkawinan Siri Berbasis Nilai Keadilan.” Jurnal Pembaruan Hukum 2, no. 2 (2015).

Olivia, Fitria. "Akibat Hukum Terhadap Anak Hasil Perkawinan Siri Pasca Putusan Mahkamah Konstitusi.” Lex Jurnalica 11, no. 1 (2014).

\section{Peraturan Perundang-Undangan:}

Undang-Undang Dasar Negara Republik Indonesia Tahun 1945.

Kitab Undang-Undang Hukum Perdata.

Undang-Undang Nomor 1 Tahun 1974 Tentang Perkawinan.

Undang-Undang Nomor 23 Tahun 2002 Tentang Perlindungan Anak.

Inpres Nomor 1 Tahun 1991 Tentang Kompilasi Hukum Islam 


\section{Media Online}

http://www.rumahpintarr.com/2016/09/5-penyebab-dan-penghalang-mendapatkan $. h t m l ? m=1$ 